\title{
Species diversity, stand productivity, aboveground biomass, and economic value of mangrove ecosystem in Mentawir Village, East Kalimantan, Indonesia
}

\author{
ROCHADI KRISTININGRUM ${ }^{1}$, ABUBAKAR M. LAHJIE ${ }^{1, \vee}$, MASJAYA $^{2}$, SYAHRIR YUSUF $^{1}$, YOSEP RUSLIM $^{1, \vee v}$ \\ ${ }^{1}$ Faculty of Forestry, Universitas Mulawarman. Jl. Penajam, Kampus Gunung Kelua, Samarinda 75123, East Kalimantan, Indonesia. \\ Tel.: +62-541-735089Fax.: +62-541-735379, •email: prof_abudir@yahoo.com, •`email:yruslim@gmail.com \\ ${ }^{2}$ Faculty of Social and Political Science, University Mulawarman. Jl. Muara Muntai, Kampus Gunung Kelua, Samarinda 75123, East Kalimantan, \\ Indonesia
}

Manuscript received: 31 August 2019. Revision accepted: 5 September 2019.

\begin{abstract}
Kristiningrum R, Lahjie AM, Masjaya, Yusuf S, Ruslim Y. 2019. Species diversity, stand productivity, aboveground biomass, and economic value of mangrove ecosystem in Mentawir Village, East Kalimantan, Indonesia. Biodiversitas 20: 2848-2857. Mangrove forest is one of the important ecosystems. It provides a variety of benefits both ecologically and economically. There are many biodiversity values of mangrove ecosystems that it can be evaluated economically. This study aims to: (i) identify the species diversity of mangrove forest; (ii) analyze the mangrove productivity and aboveground biomass; (iii) analyze the ecosystem value of mangrove forest in Mentawir Village, Penajam Paser District, East Kalimantan Province. The research used systematic random sampling method by establishing two plots with extent of one hectare for each plot in which each plot was divided into $20 \mathrm{~m} \times 20 \mathrm{~m}$ subplots. The volume and mean annual increment (MAI), as well as current annual increment (CAI), were calculated. Economic value of mangrove ecosystem was calculated using Contingent Valuation Method (CVM) to reveal the total margin between Willingness to Pay (WTP) of wood produced by mangrove forest and Willingness to Accept (WTA) of fisheries catches. The results showed that there were 12 species of mangroves in the studied areas in which Rhizophora apiculata was the dominant species. Total aboveground biomass in Plot I and Plot II were respectively 127.46 tons $\mathrm{ha}^{-1}$ (62.61 tons $\left.\mathrm{C} \mathrm{ha}^{-1}\right)$ and 79.26 (38.85 tons $\mathrm{C}^{-1}$ ) and dominated by Rhizophoraceace family with $76.80 \%$, while $23.22 \%$ of the biomass was contributed by other mangrove families. The mangrove forest had a maximum average volume increment at 48 years and 42 years with MAI of $2.97 \mathrm{ha}^{-1} \mathrm{yr}^{-1}$ and $2.12 \mathrm{~m}^{3} \mathrm{ha}^{-1} \mathrm{yr}^{-1}$ at Plot I and Plot II, respectively, with the total volume reached $127.5 \mathrm{~m}^{3} \mathrm{ha}^{-1}$ and $79.60 \mathrm{~m}^{3} \mathrm{ha}^{-1}$. The calculation of total margin between WTP and WTA indicated that in economic value of mangrove ecosystem in Mentawir Village with an extent of 2,300 ha was between IDR 207,000,000 $\mathrm{yr}^{-1}$ and IDR 345,000,000 $\mathrm{yr}^{-1}$. Our findings suggest that a good mangrove ecosystem will result in high economic value and biodiversity values cannot be separated from economic benefits in order to protect its sustainability.
\end{abstract}

Keywords: Biomass, diversity, economic value, ecosystem mangrove, stand productivity

\section{INTRODUCTION}

Mangrove is a unique ecosystem that only covers about $2 \%$ of total land surface of the earth. Globally, half of all mangrove forests have been lost since the mid-20th century, with one-fifth have gone since 1980 alone (Spalding et al. 2010). The loss of mangroves is likely caused by the poor perception and inadequate knowledge of the general public about the economic and ecological values of mangroves (Feka and Ajonina 2011). These values include the ecosystem services provided by mangroves, such as the habitat of fish, flood prevention, erosion prevention, water regulation, and timber products.

Indonesia has the largest mangrove ecosystem in the world, consisting of $27 \%$ (16.9 million ha) of the total world mangrove forest, and is a center of distribution of biodiversity of mangrove species and ecosystem (Spalding et al. 2010), yet it undergoes rapid and dramatic destruction (Setyawan et al. 2003). Mangroves are invaluable treasure for Indonesian biodiversity with immense ecological and economic significances (Hema and Devi 2015). Mangrove ecosystem has also high economic value both directly and indirectly as this ecosystem is one of the sources of income that is very useful for the community and the country. As such, its existence needs to be preserved and valuated (Oktawati and Sulistianto 2015).

Valuation of ecosystem services is critical to evaluate and analyze the services provided by an ecosystem (Turner et al. 2010), including in mangrove ecosystem. Ecosystem services valuation techniques can be done in economic and non-economic terms (Elegbede et al. 2015). Yet, a coherent review of the valuation of coastal ecosystem services (CES) is still lacking (Mehvar et al. 2018). Wijaya (2018) states that one of the leading research themes in 2019-2023 is the quantification and valuation of coastal ecosystem services.

The valuation of ecosystem services is a complex process as it includes several dimensions (ecological, socio-cultural and economic) and not all of these can be quantified in monetary units (Mukherjee et al. 2014; Kamaludin et al. 2018; Darmawan 2015). Barbier et al. (2011) state that some of these economic valuation methods depend on the value of ecosystem services and some are dependent on the non-market approach. Until 
now, valuation methods, data and classification systems for ecosystems were developed predominantly for terrestrial ecosystems while coastal ecosystems have received scant attention (Barbier et al. 2011; Liquete et al. 2013; Ezebilo 2016). Peer-reviewed literature on global economic valuations of coastal ecosystems like mangrove forest is rather limited (Brander et al. 2012; Salem and Mercer 2012). For instance, mangroves are either mixed with tidal marshes (wetlands) in Costanza et al. (2014) or divided into 'tropical forests', 'coastal systems' and 'coastal wetlands' in De Groot et al. (2012).

Pearce and Ozdemiroglu (2002) stated that goods and services that positively contribute to human well-being have economic values. Contingent Valuation Method (CVM) is one of the methods used to carry out economic valuation (Pearce and Moran 1994; Chea 2013). CVM enables economic values to be estimated for a wide range of non-traded commodities in the market. The economic value is reflected through individual's willingness for the payment (i.e. willingness to pay/ WTP) for the usage and utilization of the environment (Suprapto et al. 2016). One is willing to pay high prices if he/she attain high social values from the services. Furthermore, Oktawati and Sulistianto (2015) stated that WTP can also reflect the willingness to pay for environmental quality improvement. In sum, WTP is the maximum amount of people will be willing to pay, sacrifice or exchange to receive the good or to avoid something undesirable, such as pollution. This term is contrary to Willingness To Accept Payment (WTA), which is the minimum amount an individual or company who are willing to accept to deliver goods or receive something that is not desirable. A transaction occurs when the willingness to pay is higher than the market price (Putri et al. 2017).

East Kalimantan is one of the provinces in Indonesia with various natural resources including non-recoverable resources such as oil, gas, coal and mineral resources, and recoverable resources such as timber, fish, seaweed and mangrove resources. It is the second-largest province in Indonesia with an area of $245,237.80 \mathrm{~km}^{2}$ or $11 \%$ of the total land area of Indonesia (Wahyuni et al. 2014). Balikpapan Bay is a strategic port in the province of East Kalimantan, Indonesia. The Balikpapan Bay area consists of waters with an area of 16,000 ha and land area of 156,836 ha. The population in Balikpapan grows rapidly with growth of $3.2 \%$ a year from 2010 and an estimated 720,000 people living in this area. It is estimated that 108,200 people live around the sub-watershed that flows into Balikpapan Bay. The development in Balikpapan Bay has caused damage to mangrove ecosystems by $47.6 \%$ and resulted in a decrease of the extent of mangrove forests by around $12.5 \%$ in the last 15 years (Lahjie et al. 2019). Whereas Warsidi and Handayani (2017) stated that mangrove forests in the Balikpapan Bay area consist of primary mangrove forests and secondary mangrove forests which are generally dominated by Rhizophora apiculata species and there are 13 mangrove species with different distribution patterns and densities. Improvement in the management practice of mangrove forest is needed especially to meet the increasing demand for wood while protecting tropical rain forest diversity (Ruslim 2011; Ruslim 2016).

There had been attempts on the economic valuation of wetland ecosystem in general (Costanza et al. 1997; Barbier 2007; Binilkumar 2010) and mangroves in particular (Lal 2003; Sathirathai 2003; Gunawardena and Rowan 2005). Therefore, the mangroves in Balikpapan Bay provides excellent case study on economic valuation of mangrove ecosystem in Indonesia. Based on the above background this study aims to: (i) identify the species of mangrove and its potentials for utilization; (ii) analyze the mangrove productivity and aboveground biomass; (iii) analyze the economic value of mangrove ecosystem of the Balikpapan Bay.

\section{MATERIALS AND METHODS}

\section{Study area and period}

The location of the study was in mangrove ecosystem in the Balikpapan Bay Area which is administratively located in Mentawir Village, Sepaku Subdistrict, Penajam Paser Utara District, East Kalimantan Province. The map of the research location is presented in Figure 1. The research was conducted for three months from April to June 2019.

\section{Procedures}

Data on mangrove was collected using systematic random sampling (Sugiyono 2015). Inventory of mangrove species was conducted at site with $1000 \mathrm{~m}$ distance from the shoreline. At this site, two plots were established with each plot covering 1 hectare. Within each plot, $20 \mathrm{~m} \times 20 \mathrm{~m}$ subplots were created, resulting in a total of 25 subplots for each plot. Mangrove diameter and height were measured to calculate the stands volume and biomass.

Social-economic data was collected using purposive sampling with selected sample of fishermen and community around the mangrove forest through direct interviews. The data collected were named, age, education, number of family members, type of fishing equipment, amount of fish production, fish selling prices and prediction of mangrove wood prices.

\section{Data analysis}

\section{Productivity of mangrove stand}

Data of mangrove species identification results were tabulated in Microsoft Excel to calculate the potentials of mangrove species at the studied area. Analysis of mangrove wood was done by calculating the total volume of standing stock and analyzing the growth increment of mangrove. The increment is an increase in tree dimension of growth (including height, diameter, basal area, and volume) and associated with tree age. Then, the mean annual increment (MAI) and current annual increment (CAI) were calculated following the equations below (Van Gardingen et al. 2003). 

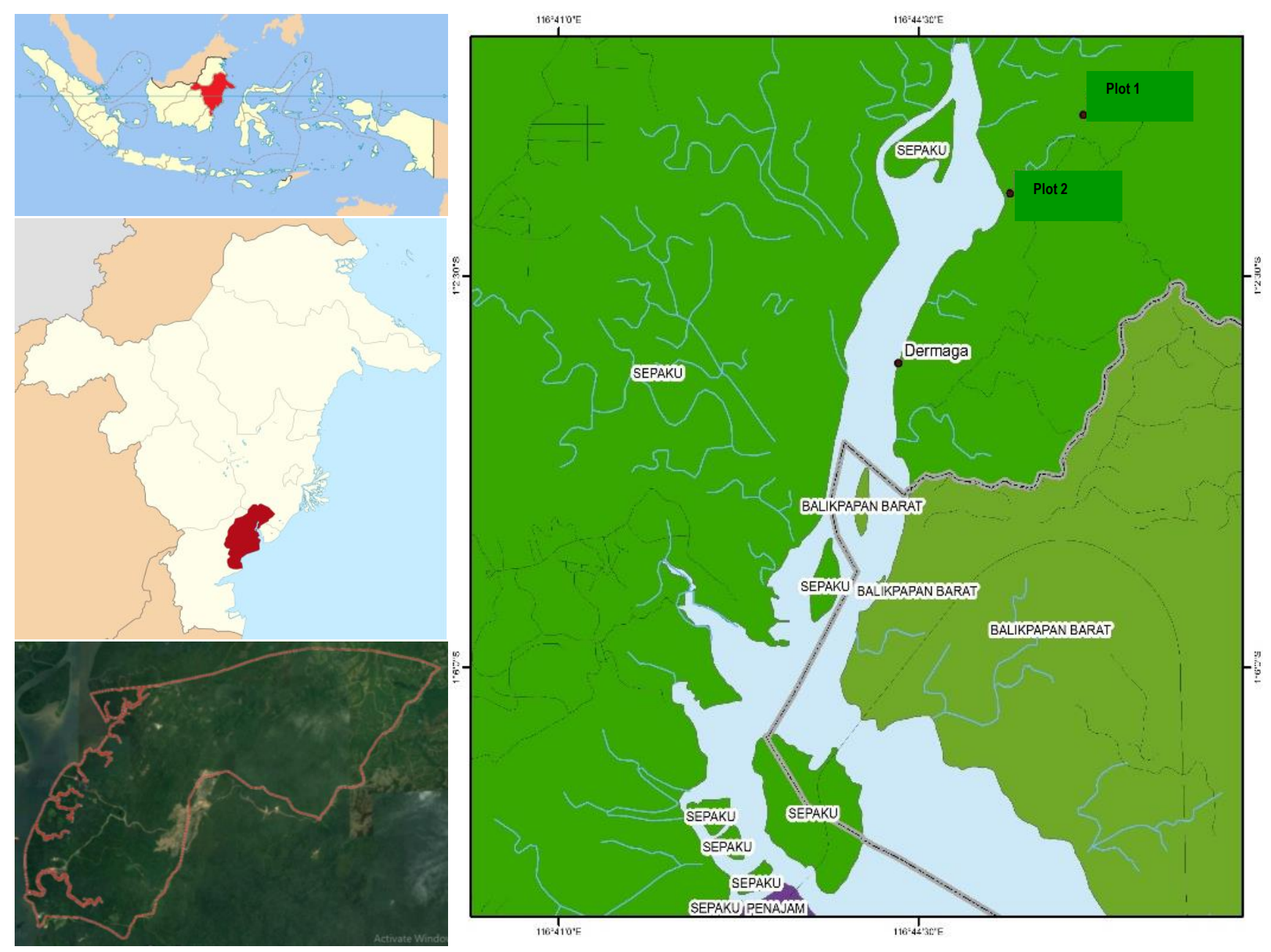

Figure 1. Research location Mentawir Village, Sepaku Subdistrict, Penajam Paser Utara District, East Kalimantan Province, Indonesia

$$
\mathrm{V}=\frac{1}{4} \Pi d^{2} h t f
$$

Where: $\mathrm{V}=$ standing volume, $\mathrm{d}=$ diameter at breast height, $\mathrm{h}=$ branch free height, $\mathrm{f}=$ form factor

$$
\mathrm{MAI}=\frac{V_{t}}{t}
$$

Where: MAI = mean annual increment, $\mathrm{Vt}=$ total standing volume at age $t, t=$ tree age. This is the annual average value of mangrove wood

$$
\mathrm{CAI}=\frac{V_{t}-V_{t-1}}{T}
$$

Where: $\mathrm{CAI}=$ current annual increment, $\mathrm{Vt}=$ total standing volume mangrove at age $\mathrm{t}, \mathrm{t}=$ tree age

The age of a mangrove stand was calculated based on the circumference measurements divided by two. This method was based on local knowledge of the community around the mangrove forest in Mentawir and has been in agreement with a study conducted by Lahjie et al. (2019) in which they found that at the age of 25 years, mangroves have an average diameter of around $15.9 \mathrm{~cm}$. Local communities are considered protectors of natural resources because they have knowledge of local culture, environment and livelihoods in the area (Adam et al. 2019).

Carbon stock was estimated from mangrove biomass referred as $50 \%$ of the value of biomass (Komiyama et al. 2008). Measurement of biomass was done in a nondestructive way. It was determined based on data from measurements of tree volume (Bismark 2008; Hairiah and Rahayu 2007; Brown 1997 and International Panel on Climate Change/IPCC 2003). To calculate biomass the following formula was used:

Biomass $=$ tree volume $\mathrm{x}$ tree specific gravity

Where: Specific gravity of Rhizophora sp. $=0.92$, Bruguiera $\mathrm{sp}=0.91$ (Bismark 2008). 
Valuation of ecosystem

Calculation the economic valuation of mangrove ecosystems was done by investigating the direct use value of mangroves. It was derived from the calculation of the total volume of mangrove wood/productivity of mangrove stand and fish catches. The calculation of economic valuation uses the contingent valuation method (CVM), which is willingness to pay (WTP) to calculate the value of wood and willingness to accept (WTA) to calculate catches. If the WTP and WTA values are known, then the balance of the WTP and WTA can be calculated.

Value assessment of willingness to pay (WTP) for services provided by coastal ecosystems is usually done to provide value appreciation for the existence of coastal ecosystems such as mangroves, reefs coral, seagrass (Halkos and Galani 2013; Malik et al. 2015; Wahyuni et al. 2014; Widiastuti et al. 2016; Saraithong 2016; Sina et al. 2017) and fish resources (Rizal and Dewanti 2017). Therefore, WTP is a value of potential uses of natural resources and environmental services (Hanley and Spash 1993). WTP indicates the strength of one's preference for environmental quality, and it is influenced typically by several factors, including income, gender, cultural preferences, education, or age (Ekka and Pandit 2012).

Contingent Valuation Method (CVM) is a survey-based approach that involves developing a hypothetical market by directly asking to an individual to state his or her willingness to pay (WTP) for the environmental services provided in a particular location and/or willingness to accept (WTA) as the compensation for any damages. In this research, CVM was used for valuing mangrove ecosystem and it aims to assess the willingness to pay of communities for the mangrove ecosystem (Mitchell and Carson 1989; Turner and Pearce 1990; and Suprapto 2016). The marginal willingness to pay was calculated by the differences in the coefficients between the two attribute levels. Households were asked about how much they would pay for a given service level, describing at which level they were willing to contribute to experience a transformation of something (Kamaludin et al. 2018). In this study, the calculation of WTP and WTA was derived from the calculation of the total income from mangrove wood production and yields from fisheries catches. Where both form a point of intersection called the margin (balance). However, in this research, the approaching model with WTP of wood was assumed as the ability of the community to pay for natural and environmental services in mangrove conservation activities whose value is obtained from the mangrove wood. While the WTA of fish catch approach model is assumed as a willingness from the community to receive compensation (in the form of funds) derived from fisheries catches. The value of the margin (profit) from both the WTP and the WTA was made as the balance value and calculated as follows:

$$
\mathrm{AW}=\frac{T W}{t}
$$

Where: $\mathrm{AW}=$ average willingness, $\mathrm{TW}=$ total willingness at age $\mathrm{t}, \mathrm{t}=$ age

$$
\mathrm{MW}=\frac{W_{t}-W_{t-1}}{T}
$$

Where: $\mathrm{MW}=$ marginal willingness, $\mathrm{W}_{\mathrm{t}}=$ total willingness at age $\mathrm{t}, \mathrm{W}_{\mathrm{t}-1}=$ total willingness at age $\mathrm{t}-1, \mathrm{~T}=$ time interval between each measurement age, both to pay and to accept (MWTP or MWTA) i.e Marginal willingness to pay (MWTP) from wood and marginal willingness to accept from catch.

\section{RESULTS AND DISCUSSION}

\section{Mangrove ecosystem overview}

Mentawir Village is one of four villages in Sepaku Subdistrict, Penajam Paser Utara District and located at the eastern end of Penajam Paser Utara District and directly borders with Kutai Kartanegara District and Balikpapan Municipality. Mentawir Village has a land area of $\pm 22,222$ ha consisting of four neighborhoods.

Total mangroves in Mentawir Village reaches an extent of 2,300 ha. The types of mangroves in the area are quite diverse with different distribution patterns and densities. The results of identification of mangrove showed that in Mentawir Village there were 12 species of mangrove including Rhizophora apiculata, Rhizophora mucronata, Sonneratia alba, Sonneratia caseolaris, Avicennia alba, Bruguiera gymnorrhiza, Bruguiera parviflora, Ceriops tagal, Xylocarpus granatum, Scyphiphora hydrophyllacea, Nypa fruticans, and Acrosticum aureum. This result is lower than the study by Warsidi and Endayani (2017) that found as many as 20 species of mangroves in Balikpapan Bay. However, our result is higher than the research by Oktawati and Sulistianto (2013) in Kariangau village, Balikpapan Municipality which only found four species of mangroves namely $R$. mucronata, $R$. stylosa, A. alba, and $N$. fruticans. The condition of mangrove is presented in Figure 2.

When compared with the results of research in other regions, it shows that species richness of mangrove in Balikpapan Bay area is higher. Darmadi and Ardhana (2010) found that in Perapat Benoa mangrove forest in Pemogan village, South Denpasar sub-district, Denpasar Municipality, Bali Province, there were only seven species of mangrove. Meanwhile, the mangroves in Kumu village, Tombariri District, Minahasa District consisted of only three species of mangroves namely $R$. apiculata, A. alba and $S$. alba (Nauw 2012). The higher species richness in Mentawir is likely caused by ecosystem conditions in this area which is still classified as good enough to support various mangrove species especially in term of sediments that contain a lot of mud which is generally richer in organic matter compared to sandy sediments (Ati et al. 2014). According to Sulistiyowati (2009) mangrove species of Rhizophora sp. has higher adaptability than other genera and Rhizophora sp. can grow at a salinity of 32-34 ppt (Kolinug et al. 2014). 


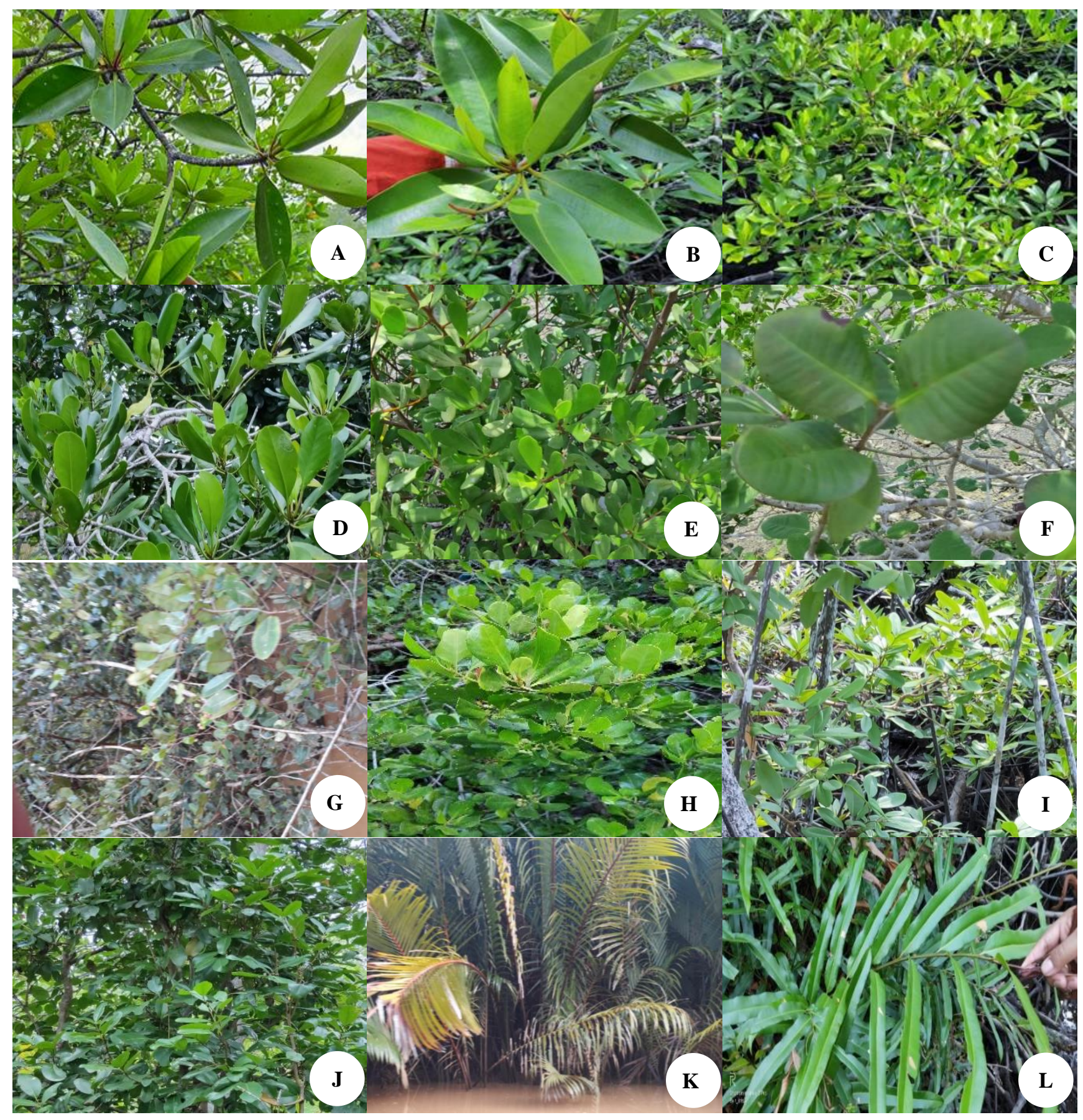

Figure 2. Types of mangroves in the Mentawir Village, Sepaku Subdistrict, Penajam Paser Utara District, East Kalimantan Province, Indonesia. A. Rhizophora apiculata, B. Rhizophora mucronata, C. Bruguiera gymnorizha, D. Bruguiera parviflora, E. Avicennia alba, F. Sonneratia alba, G. Sonneratia caseolaris, H. Scyphiphora hydrophyllacea, I. Ceriops tagal, J. Xylocarpus granatum, K. Nypa fruticans, L. Acrosticum aureum

Mangrove forests, including trees and shrubs, consisting of eight families and 12 genera, namely: Avicennia, Sonneratia, Rhizophora, Bruguiera, Ceriops, Xylocarpus, Lummitzera, Laguncularia, Aegiceras, Aegiatilis, Snaeda and Cononocarpus (Bengen 2001). Mangrove ecosystems in Indonesia are dominated by Rhizophora, Avicennia, Bruguiera, and Sonneratia (Nybakken 1992). In addition, the mangrove ecosystem also found plants species Ceriops, Xylocarpus, Acrostichum, Lumnitzera, Aegiceras, Scyphyphora, and Nypa (Supriharyono 2009). According to Bengen (2001), the distribution and zoning of mangrove forests depend on various environmental factors. In Indonesia, the zoning of mangrove forest can be divided into: (i) The area closest to the sea, with a subtle sandy substrate, often overgrown by Avicennia spp. In this zone, Sonneratia spp. is usually 
associated and predominantly grows in deep sludge which is rich in organic matter. (ii) Zone toward landward, mangrove forests is generally dominated by Rhizophora spp. In this zone, Bruguiera spp. and Xylocarpus spp. are also found. (iii) The transition zone between mangrove forest and lowland forest is usually overgrown by Nypa fruticans and several other palm species.

\section{Biomass and carbon content of mangrove}

In general, there were 12 species of mangroves at the research location, but for biomass analysis, there were five species belongs to the family Rhizophoraceace being the object in determining biomass and carbon content, namely $R$. apiculata, $R$. mucronata, $B$. gymnorrhiza, B. parviflora and Ceriops tagal. The biomass and carbon content at Plot I and Plot II are shown in Table 1.

In this study, the measurements of mangroves biomass were carried out in the section above ground. Kusmana et al. (1992) stated that the amount of biomass is determined by the diameter, height of the plant, density of wood, and soil fertility. Brown (1997) and IPCC (2003) states that $45 \%$ up to $50 \%$ of the plant's dry matter consists of carbon content. Table 1 shows that total biomass at plot I and plot II were respectively 127.46 tons $\mathrm{ha}^{-1}$ (62.61 tons $\mathrm{C} \mathrm{ha} \mathrm{ha}^{-1}$ ) and 79.26 ( 38.85 tons $\left.\mathrm{C} \mathrm{ha}^{-1}\right)$. The average value of mangrove forest biomass at the studied area in Mentawir Village is 103.36 tons $\mathrm{ha}^{-1}\left(50.73\right.$ tons $\left.\mathrm{C} \mathrm{ha}^{-1}\right)$. There were five species belongs to the family Rhizophoraceace that has the highest biomass. At Plot I (20 m x $20 \mathrm{~m}), R$. apiculata has the highest biomass with 55.19 tons ha $^{-1}$ (27.60 tons C $\left.\mathrm{ha}^{-1}\right)$ followed by $R$. mucronata with 19.12 tons ha ${ }^{-1}(9.56$ tons $\mathrm{C} \mathrm{ha}^{-1}$ ) and B. gymnorrhiza 11.85 tons ha ${ }^{-1}$ (5.93 tons $\mathrm{C}$ ha $\left.^{-1}\right)$, while the lowest is Nypa fruticans with 2.55 tons $\mathrm{ha}^{-1}$ (0.64 tons $\left.\mathrm{C} \mathrm{ha}{ }^{-1}\right)$ and A. aureum 1.91 tons ha $\mathrm{ha}^{-1}(0.48$ tons $\left.\mathrm{C} \mathrm{ha}^{-1}\right)$. While at Plot II $(20 \mathrm{~m}$ x $20 \mathrm{~m}), R$. apiculata has biomass of 33.81 tons ha' ${ }^{-1}\left(16.91\right.$ tons $\left.\mathrm{C} \mathrm{ha}^{-1}\right)$ followed by $R$. mucronata with 10.75 tons ha-1 (5.38 tons $\mathrm{C} \mathrm{ha}^{-1}$ ) and B. gymnorrhiza with 8.40 tons ha $\mathrm{h}^{-1}$ (4.20 tons $\left.\mathrm{C} \mathrm{ha}^{-1}\right)$, while the lowest is Nypa fruticans with 1.75 tons $\mathrm{ha}^{-1}(0.44$ tons $\left.\mathrm{C} \mathrm{ha}^{-1}\right)$ and A. aureum 1.35 tons ha ${ }^{-1}\left(0.34\right.$ tons $\left.\mathrm{C} \mathrm{ha}^{-1}\right)$.

Table 1. Biomass and carbon content of each species of mangrove at Plot I and Plot II

\begin{tabular}{lcccc}
\hline \multirow{2}{*}{\multicolumn{1}{c}{ Species }} & \multicolumn{2}{c}{$\begin{array}{c}\text { Biomass } \\
\text { (tons ha }\end{array}$} & \multicolumn{2}{c}{$\begin{array}{c}\text { Carbon } \\
\text { (tons C ha }\end{array}$} \\
\cline { 2 - 6 } & Plot I & Plot II & Plot I & Plot II \\
\hline Rhizophora apiculata & 55.19 & 33.81 & 27.60 & 16.91 \\
Rhizophora mucronata & 19.12 & 10.75 & 9.56 & 5.38 \\
Bruguiera gymnorrhiza & 11.85 & 8.40 & 5.93 & 4.20 \\
Bruguiera parviflora & 7.27 & 5.20 & 3.63 & 2.60 \\
Avicennia alba & 6.12 & 3.71 & 3.06 & 1.85 \\
Soneratia alba & 5.35 & 3.24 & 2.68 & 1.62 \\
Soneratia caseolaris & 5.10 & 3.09 & 2.55 & 1.54 \\
Scyphiphora hydrophyllacea & 4.59 & 2.78 & 2.29 & 1.39 \\
Ceriops tagal & 4.46 & 2.70 & 2.23 & 1.35 \\
Xylocarpus granatum & 3.95 & 2.48 & 1.98 & 1.24 \\
Nypa fruticans & 2.55 & 1.75 & 0.64 & 0.44 \\
Acrostichum aureum & 1.91 & 1.35 & 0.48 & 0.34 \\
Total & 127.46 & 79.26 & 62.61 & 38.85 \\
Average & \multicolumn{2}{c}{103.36} & 50.73 \\
\hline
\end{tabular}

Of the 12 species of mangroves in Mentawir Village, it turns out that the aboveground biomass either at Plot I or Plot II is dominated by Rhizophoraceace family with $76.80 \%$, while $23.22 \%$ of the biomass is contributed by other mangrove families. The biomass of mangrove forests in Mentawir which is part of the Balikpapan Bay Area is one and a half times higher than that in Siberut Island, West Sumatra, which is 49.13 tons ha-1 (Bismark 2008). The low biomass of mangrove in Siberut Island is likely caused by the low levels of $\mathrm{P}$ and cation exchange capacity. The high organic carbon content of sediments in the existing mangroves in Mentawir is presumably due to the difference in age of mangroves, which is marked by the large size of the diameter of the mangrove. The longer the age of the mangrove, the more organic matter being decomposed. In addition, the study location was dominated by Rhizophora sp. in which this species grows well on muddy substrates. Ati et al. (2014) and Kusmana et al. (2003) stated that muddy sediments are generally richer in organic matter compared to sandy sediments.

\section{Potential productivity of mangrove stand}

The analysis of mangrove wood volume is used to find out how much volume of mangrove wood can be produced in each hectare to infer the direct benefits of mangrove forests. At Plot 1, there were 438 of mangrove trees with height ranged from 6 to $11 \mathrm{~m}$ (average height of $8.1 \mathrm{~m}$ ) and diameters of 17 to $36 \mathrm{~cm}$ (average diameter of $27 \mathrm{~cm}$ ), inferring that the ages of the mangrove trees ranged from 27 to 57 years. The results of analysis showed that the maximum potential of wood production of mangroves was achieved at the age of 48 years with a total volume of 14.48 $\mathrm{m}^{3} \mathrm{ha}^{-1}$, with a maximum increment of MAI and CAI at 0.30 and $0.31 \mathrm{~m}^{3} \mathrm{ha}^{-1}$ year $^{-1}$, respectively (Table 2). In total, in 1 hectare of Plot I there was 438 trees with a total volume of $127.46 \mathrm{~m}^{3} \mathrm{ha}^{-1}$ and MAI and CAI increments of 2.97 and $3.36 \mathrm{~m}^{3} \mathrm{ha}^{-1}$ year $^{-1}$, respectively. The high increment of MAI and CAI indicates high soil fertility. As the optimal mangrove increment was achieved at the age of 48 years, while after the age of 48 years, mangrove increment decreased from 0.30 to 0.27 . According to the biological cycle of tree stand in which the stand will harvest when MAI is equal to CAI, the timber cutting rotation of mangrove at Plot 1 is 48 years (Figure 3 ).

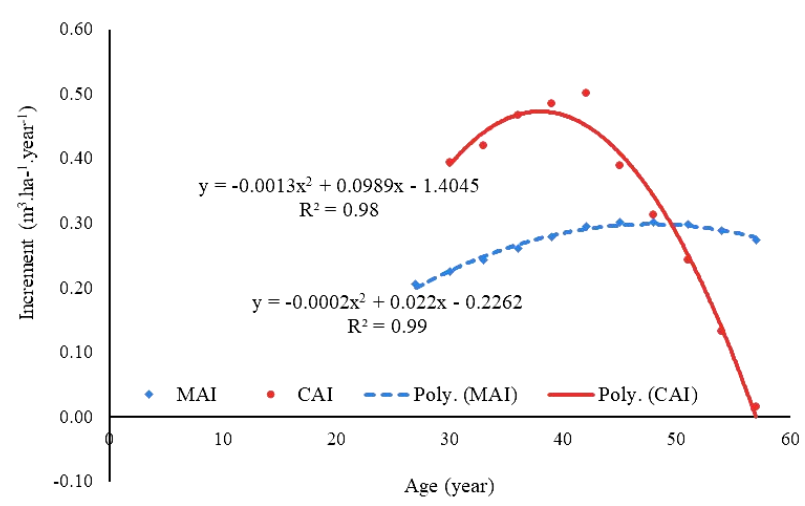

Figure 3. Standing volume increment of mangrove stands at Plot 
According to Dinga (2014), Muliadi et al. (2017) and Winarni et al. (2017), the graph exhibits certain characteristics which can be explained as follow: CAI curve rapidly reached the peak and declined sharply, whereas MAI curve both climbed and declined gradually. In the beginning, MAI was lower than CAI, and CAI reached the peak preceding MAI. After reaching the peak, CAI declined and at a particular point intersected with MAI. The intersection point of MAI and CAI occurred at the age of 48 years. After the intersection point, both MAI and CAI declined, indicating a decreasing trend in the volume increment. At the age of 48 years, the mean annual standing volume increment of mangrove tree has reached the maximum. It indicates that the maximum production potential of the timber had been attained and the tree was ready to be cut down. The total increment of MAI and CAI mangrove in 1 hectare is respectively 2.97 and $3.36 \mathrm{~m}^{3} \mathrm{ha}^{-1}$ year $^{-1}$. This is lower than the research conducted by Lahjie et al. (2019), that the highest growth increment of mangrove wood production was reached at the age of 25 years, and the highest value of MAI was $5.39 \mathrm{~m}^{3} \mathrm{ha}^{-1}$. A study by Lahjie et al. (2019) was carried out on mangroves that had undergone restoration, namely the second generation and maximum increment was achieved at the age of 25 years, while this study was carried out on natural mangroves in which growth was very slow and maximal increment was achieved at age 48 year. So that the mangrove increment in Mentawir Village is half of the mangrove increment that has undergone restoration. This is supported by a simple linear regression test with a polynomial type has an $\mathrm{R}^{2}$ of $98 \%$. This value means that there is a close relationship between age and increment with $98 \%$, while $2 \%$ is influenced by other factors.

At Plot II, the mangrove trees had diameter from 13 to $32 \mathrm{~cm}$ with an average of $22.9 \mathrm{~cm}$, meaning that the age ranged from 21 to 51 years, the height ranged from 3.2 to 8.3 meters with an average height of $5.6 \mathrm{~m}$ (Table 3). At Plot II, the maximum potential of wood production was achieved at the age of 42 years with a total volume of 9.64 $\mathrm{m}^{3} \mathrm{ha}^{-1}$, with a maximum increment of MAI and CAI in the respective row are 0.23 and $0.29 \mathrm{~m}^{3} \mathrm{ha}^{-1}$ year $^{-1}$ (Table 3). In one hectare of Plot I, there was 517 trees with a total volume of $79.60 \mathrm{~m}^{3} \mathrm{ha}^{-1}$ and MAI and CAI increments for 2.12 and $2.70 \mathrm{~m}^{3} \mathrm{ha}^{-1}$ year $^{-1}$, respectively. The optimal mangrove increment is achieved at the age of 42 years and after this age, mangrove increment decreased from 0.23 to 0.21 in which the curve of CAI and MAI intersected. This means that timber cutting rotation of mangrove stand at Plot II was 42 years. This is supported by a simple linear regression test with the type of polynomial on MAI has an $\mathrm{R}^{2}$ of $98 \%$ whereas the CAI has an $\mathrm{R}^{2}$ of $89 \%$ (Figure 4 ).

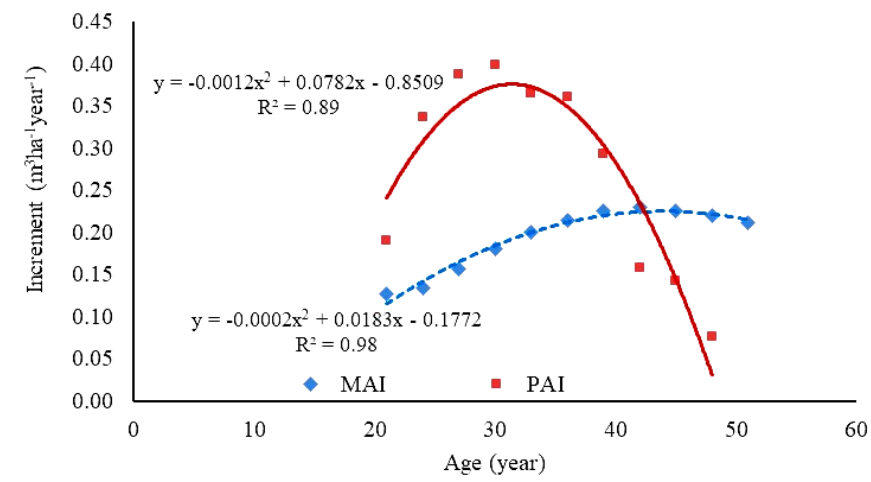

Figure 4. Standing volume increment of mangrove stands at Plot II

Table 2. Growth increment potential of mangrove stands at Plot I

\begin{tabular}{lccccccc}
\hline Age & $\mathbf{n}$ & $\mathbf{d}$ & $\mathbf{h}$ & $\mathbf{f}$ & TV & MAI & CAI \\
\hline 27 & 50 & 17 & 6.0 & 0.80 & 5.57 & 0.21 & \\
30 & 45 & 19 & 6.8 & 0.77 & 6.75 & 0.23 & 0.39 \\
33 & 44 & 21 & 7.0 & 0.75 & 8.01 & 0.24 & 0.42 \\
36 & 44 & 23 & 7.2 & 0.72 & 9.41 & 0.26 & 0.47 \\
39 & 44 & 25 & 7.5 & 0.68 & 10.87 & 0.28 & 0.49 \\
42 & 44 & 27 & 7.7 & 0.65 & 12.37 & 0.29 & 0.50 \\
45 & 40 & 29 & 8.2 & 0.64 & 13.54 & 0.30 & 0.39 \\
$\mathbf{4 8}$ & $\mathbf{3 7}$ & $\mathbf{3 1}$ & $\mathbf{8 . 6}$ & $\mathbf{0 . 6 2}$ & $\mathbf{1 4 . 4 8}$ & $\mathbf{0 . 3 0}$ & $\mathbf{0 . 3 1}$ \\
51 & 35 & 32 & 9.2 & 0.57 & 15.20 & 0.30 & 0.24 \\
54 & 30 & 34 & 10.0 & 0.56 & 15.60 & 0.29 & 0.13 \\
57 & 25 & 36 & 11.0 & 0.55 & 15.65 & 0.27 & 0.02 \\
Sum & $\mathbf{4 3 8}$ & & & & $\mathbf{1 2 7 . 4 6}$ & $\mathbf{2 . 9 7}$ & $\mathbf{3 . 3 6}$ \\
\hline
\end{tabular}

Note : $\mathrm{n}=$ number of trees $\left(\right.$ tree.ha $\left.^{-1}\right), \mathrm{d}=$ tree diameter $(\mathrm{cm}), \mathrm{h}=$ branch tree height $(\mathrm{m}), \mathrm{f}=$ tree form factor, $\mathrm{TV}=$ total volume $\left(\mathrm{m}^{3} \mathrm{ha}^{-1}\right)$, MAI $=$ mean annual increment $\left(\mathrm{m}^{3} \mathrm{ha}^{-1}\right.$ year $\left.^{-1}\right)$, CAI $=$ current annual increment $\left(\mathrm{m}^{3} \mathrm{ha}^{-1}\right.$ year $\left.^{-1}\right)$

Table 3. Growth increment potential of mangrove stands at Plot II

\begin{tabular}{lccccccc}
\hline Age & $\mathbf{n}$ & $\mathbf{d}$ & $\mathbf{h}$ & $\mathbf{f}$ & TV & MAI & CAI \\
\hline 21 & 72 & 13 & 3.2 & 0.82 & 2.65 & 0.13 & \\
24 & 62 & 15 & 3.5 & 0.81 & 3.22 & 0.13 & 0.19 \\
27 & 57 & 17 & 4.0 & 0.80 & 4.23 & 0.16 & 0.34 \\
30 & 52 & 19 & 4.7 & 0.77 & 5.39 & 0.18 & 0.39 \\
33 & 50 & 21 & 5.0 & 0.76 & 6.59 & 0.20 & 0.40 \\
36 & 47 & 23 & 5.5 & 0.72 & 7.68 & 0.21 & 0.36 \\
39 & 45 & 25 & 6.0 & 0.67 & 8.76 & 0.22 & 0.36 \\
$\mathbf{4 2}$ & $\mathbf{4 0}$ & $\mathbf{2 7}$ & $\mathbf{6 . 6}$ & $\mathbf{0 . 6 5}$ & $\mathbf{9 . 6 4}$ & $\mathbf{0 . 2 3}$ & $\mathbf{0 . 2 9}$ \\
45 & 35 & 29 & 7.0 & 0.64 & 10.11 & 0.22 & 0.16 \\
48 & 30 & 31 & 7.6 & 0.63 & 10.54 & 0.22 & 0.14 \\
51 & 27 & 32 & 8.3 & 0.58 & 10.77 & 0.21 & 0.08 \\
Sum & $\mathbf{5 1 7}$ & & & & $\mathbf{7 9 . 6 0}$ & $\mathbf{2 . 1 2}$ & $\mathbf{2 . 7 0}$ \\
\hline
\end{tabular}

Note $: \mathrm{n}=$ number of trees $\left(\right.$ tree $\left.^{-1} \mathrm{~h}^{-1}\right), \mathrm{d}=$ tree diameter $(\mathrm{cm})$, $\mathrm{h}=$ branch tree height $(\mathrm{m}), \mathrm{f}=$ tee form factor, $\mathrm{TV}=$ total volume $\left(\mathrm{m}^{3} \mathrm{ha}^{-1}\right), \mathrm{MAI}=$ mean annual increment $\left(\mathrm{m}^{3} \mathrm{ha}^{-1} \cdot\right.$ year $\left.^{-1}\right)$, CAI $=$ current annual increment $\left(\mathrm{m}^{3} \mathrm{ha}^{-1}\right.$.year $\left.{ }^{-1}\right)$. 


\section{Willingness to Pay (WTP) of mangrove wood and Willingness to Accept (WTA) of fish caught}

Table 4 shows that the WTP from mangrove wood at Plot $\mathrm{I}$ is assumed to be the costs that must be spent by the community to pay for natural/environmental services starting at the age of 30 to 57 years to accord with the mangrove stand potential data (Table 2). The total value of WTP to be paid from 30 to 57 years was IDR 3.42 to 8.12 million ha ${ }^{-1}$ with annual WTP (AWTP) was IDR 0.11 to 0.15 million ha $^{-1}$ year $^{-1}$. The optimal point of AWTP and MWTP was achieved at the age of 48 years with costs incurred of 0.15 IDR million ha $^{-1}$ year $^{-1}$. Whereas the WTA is assumed as the amount of compensation funds received by the community due to natural or environmental services in the form of fisheries catches starting at the age of 30 to 57 years. Total WTA that can be received from 30 to 57 years was from IDR 5.14 to 8.93 million ha $^{-1}$ with annual WTA (AWTA) was from IDR 0.17 to 0.15 million $\mathrm{ha}^{-1}$ year $^{-1}$. The optimal point of AWTA and MWTA (indicated by the intersection point as presented in Figure 5) was reached at the age of 48 years with the amount of funds received at IDR 0.15 million $\mathrm{ha}^{-1}$ year $^{-1}$.

Table 5 shows that the WTP from mangrove wood at Plot II started at the age of 24 to 51 years. The total value of WTP to be paid from year 24 to year 51 was from IDR 1.60 to 4.46 million $\mathrm{ha}^{-1}$ with annual WTP (AWTP) was from IDR 0.07 to 0.09 million $\mathrm{ha}^{-1} \mathrm{year}^{-1}$. The optimal point of AWTP and MWTP was reached at the age of 39 years with the costs incurred of IDR 0.09 million ha ${ }^{-1}$ year $^{-1}$. The total WTA that can be received from year 24 to year 51 was IDR 2.54 to 4.94 million ha $^{-1}$ with annual WTA (AWTA) IDR 0.09 to 0.11 million ha $^{-1}$ year $^{-1}$. The optimal point of AWTA and MWTA at Plot II was reached at the age of 39 years (Figure 6) with the amount of funds received of IDR 0.09 million ha $^{-1}$ year $^{-1}$.

Table 4. WTP of mangrove wood and WTA of fish catch at Plot I

\section{Year TWTP AWTP MWTP Year TWTA AWTA MWTA}

\begin{tabular}{|c|c|c|c|c|c|c|c|}
\hline & 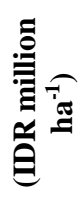 & 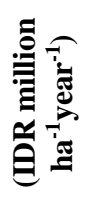 & 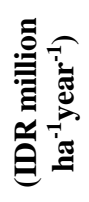 & & 总 & 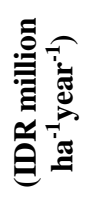 & 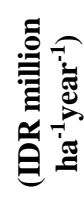 \\
\hline 30 & 3.42 & 0.11 & 0.38 & 30 & 5.22 & 0.17 & 0.03 \\
\hline 33 & 4.36 & 0.13 & 0.31 & 33 & 5.39 & 0.16 & 0.05 \\
\hline 36 & 5.14 & 0.14 & 0.26 & 36 & 5.60 & 0.16 & 0.07 \\
\hline 39 & 5.79 & 0.15 & 0.22 & 39 & 5.95 & 0.15 & 0.12 \\
\hline 42 & 6.33 & 0.15 & 0.18 & 42 & 6.34 & 0.15 & 0.13 \\
\hline 45 & 6.79 & 0.15 & 0.15 & 45 & 6.79 & 0.15 & 0.15 \\
\hline 48 & 7.24 & 0.15 & 0.15 & 48 & 7.24 & 0.15 & 0.15 \\
\hline 51 & 7.69 & 0.15 & 0.09 & 51 & 7.69 & 0.15 & 0.18 \\
\hline 54 & 7.96 & 0.15 & 0.05 & 54 & 8.23 & 0.15 & 0.23 \\
\hline 57 & 8.12 & 0.14 & 0.03 & 57 & 8.93 & 0.16 & $0.3 ?$ \\
\hline
\end{tabular}

Note: TWTP : total willingness to pay, AWTP: average willingness to pay, MWTP : marginal willingness to pay, TWTA : total willingness to accept, AWTA : average willingness to accept, MWTA : marginal willingness to accept
Table 5. WTP of mangrove wood and WTA of fish catch at Plot II

\begin{tabular}{|c|c|c|c|c|c|c|c|}
\hline \multirow{2}{*}{\multicolumn{2}{|c|}{ 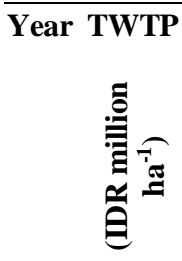 }} & \multirow{2}{*}{ 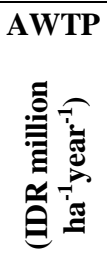 } & \multirow{2}{*}{ 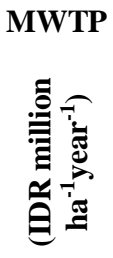 } & \multicolumn{2}{|c|}{ Year TWTA } & \multicolumn{2}{|c|}{ AWTA MWTA } \\
\hline & & & & & 总 & 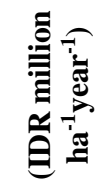 & 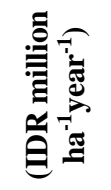 \\
\hline & & & & & & & \\
\hline & & 0.08 & 017 & & & 10 & 0.04 \\
\hline 0 & & 0.09 & & 3 & 2. & 0.09 & .06 \\
\hline 3 & 2.99 & 0.09 & 0.13 & & $3 .($ & 0.09 & .07 \\
\hline 6 & & 0.09 & & & 3.3 & 0.09 & 0.08 \\
\hline 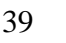 & 3.60 & 0.09 & 0.09 & 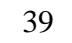 & 3.6 & 0.09 & 0.09 \\
\hline 2 & 3.8 & & 0 . & 4 & 3. & 0.09 & 0.09 \\
\hline 5 & 4.15 & 09 & 06 & 15 & 4. & 0.09 & .12 \\
\hline 48 & 4.35 & 0.09 & 0.04 & 48 & 4.51 & 0.09 & 0.14 \\
\hline 51 & 4.46 & 0.09 & 0.02 & 51 & 4.94 & 0.10 & 0.19 \\
\hline
\end{tabular}

Note: TWTP : total willingness to pay, AWTP: average willingness to pay, MWTP : marginal willingness to pay, TWTA : total willingness to accept, AWTA : average willingness to accept, MWTA : marginal willingness to accept

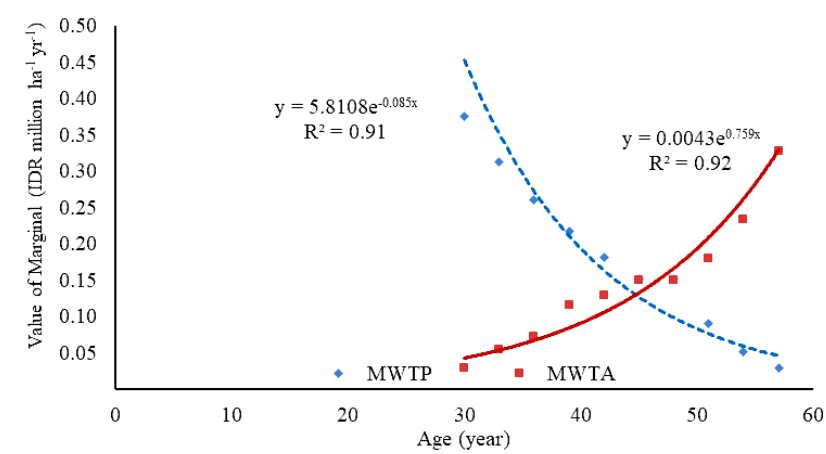

Figure 5. Margin balance between WTP of mangrove wood and WTA of fish catch at Plot I

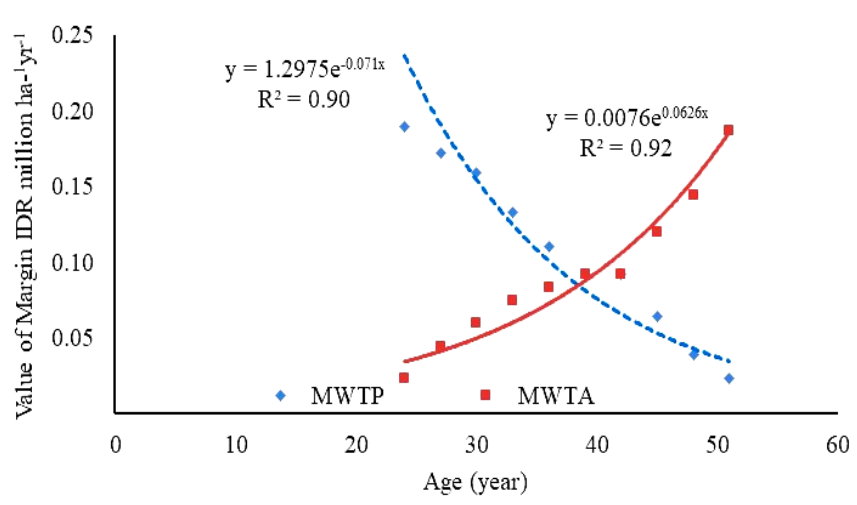

Figure 6. Margin balance between WTP of mangrove wood and WTA of fish catch at Plot II 
Considering that the total area of mangrove forests in Mentawir is 2,300 ha, the total margin of WTP and WTA at Plot I is IDR 345,000,000 year-1 and Plot II is IDR $270,000,000$ year $^{-1}$. Analysis using linear regression of WTP and WTA showed that the determination coefficient test $\left(\mathrm{R}^{2}\right)$ were more than $90 \%$, implying a close relationship between age and the marginal value of WTP and WTA.

The study may be an eye-opener which shows that the conservation of natural resources especially the mangrove ecosystem in Mentawir Village within the Balikpapan Bay Area is important and it requires the involvement of local people. The results of this study suggest that they will pay more if the ecosystems were gone. Our findings suggest that a good mangrove ecosystem will result in high economic value and biodiversity values cannot be separated from economic benefits in order to protect its sustainability. Therefore, awareness regarding conservation of mangroves needs to be increased.

\section{ACKNOWLEDGEMENTS}

This study was financially supported by postgraduate scholarships from the Ministry of Research and Higher Education. The authors would like to thank Mr. Lamale who served as key respondent at the study site and M. Rafii who helped to map the research location. We would like to thank anonymous reviewer for the constructive feedback.

\section{REFERENCES}

Adam SM, Shuib A, Ramachandran S, Kunasekaran P. 2019. Impacts of ecotourism development in Tasik Kenyir on the quality of life as perceived by the local Community. J Sustain Sci Manag 14 (3): 100109.

Ati RNA, Rustam A, Kepel TL, Sudirman N, Astrid M, Daulat A, Mangindaan P, Salim, H, Hutahaean, AA. 2014. Carbon stock and mangrove community structure as blue carbon in Tanjung Lesung, Banten. J Segara 10 (2): 98-171.

Barbier E. B. 2007. Valuing ecosystem services as productive inputs. Econ Policy 49: 178-229.

Barbier EB, Hacker SD, Kenndey C, Koch EW, Stier AC, Silliman BR. 2011.The value of estuarine and coastal ecosystem services. Ecol Monogr 81 (2):169-193.

Binilkumar AS. 2010. Economic valuation of wetland attributes: A case study of Kol lands in Kerala. [Thesis]. IIT Indian Institute of Technology, Bombay.

Bismark M, Subiandono E, Heriyanto NM. 2008. Diversity and Potential Types Carbon Content of Mangrove Forests in Subelen Siberut River, West Sumatera. Center of Forests Research and Conservation, Bogor. [Indonesian]

Bengen DG. 2001. Pedoman teknis pengenalan dan pengelolaan ekosistem mangrove. Pusat Kajian Sumberdaya Pesisir dan Lautan-Institut Pertanian Bogor. Bogor, Indonesia. [Indonesian]

Brander LM, Wagtendonk JA, Hussain SS, McVittie A, Verburg PH. 2012. Ecosystem service values for mangroves in Southeast Asia: A meta Analysis and value transfer application. J Ecosyt Serv (1): 6269.

Brown S. 1997. Estimating Biomass and Biomass Change of Tropical Forest. A Primer, FAO. Forestry Paper No. 134. FAO, Rome.

Chea CC. 2013. Choice Experiment: The benefits of living heritage conservation in Melaka City, Malaysia. Intl J Econ Bus Adm 4 (3): 83-92.

Costanza R, d'Arge R, de Groot R, Farber S, Grasso M, Hannon B, Naeem S, Limburg K, Paruelo J, O'Neill RV, Raskin RG, Sutton P, van den
Belt M. 1997. The value of the world's ecosystem services and natural capital. Nature 387: 253-260.

Costanza R, De Groot R, Sutton P, Van der Ploeg S, Anderson SJ. 2014. Changes in the global value of ecosystem services. J Glob Environ $\mathrm{Ch}$ (26): 152-158.

Darmawan. 2015. Economic valuation of ecosystem services in the Mount Menumbing Tourist Area in West Bangka Village. Padjadjaran University, Bandung. [Indonesian]

Darmadi, Ardhana. 2010. Composition types of mangrove plants in the sealed forest area Benoa Pemogan Village, South Denpasar District, Denpasar Municipality, Bali Province. J Basic Sci 11 (2): 167-171.

De Groot R, Brander L, van der Ploeg S, Costanza R, Bernard F. 2012. Global estimates of the value of ecosystems and their services in monetary units. Ecosyst Serv 1: 50-61.

Dinga E. 2014. On a possible predictor of the cyclical position of the economy. Procedia Econ Finance 8: 254-261.

Ekka, Pandit. 2012. Willingness to pay for restoration of natural ecosystem: A study of Sundarban mangroves by contingent valuation approach. Indian J Agric Econ 67 (3): 323-333.

Elegbed IO, Abimbola LHM, Saheed M, Damilola OA. 2015. Wetland resources of Nigeria: Case study of the Hadejia-Nguru Wetlands. Poult Fish Wildl Sci 2: 123. DOI: 10.4172/2375-446X.1000123.

Ezebilo E. 2016. Willingness to pay for maintenance of a nature conservation area: a case of Mount Wilhelm, Papua New Guinea. Asian Soc Sci 12 (9): 149-161.

Feka NZ, Ajonina GN. 2011. Drivers causing decline of mangroves in West Africa: A review. Int J Biodivers Sci 7 (3): 217-230.

Gunawardena, M. JS Rowan. 2005. Economic valuation of a mangrove ecosystem threatened by shrimp aquaculture in Sri Lanka. J Environ Manag 36 (4): 535-550.

Hanley N, Spash CL. 1993. Cost benefit analysis and the environment. Edward Elgar Publishing Ltd., London.

Halkos GE, Galani GK. 2013. Economic foundations to assess non-market values in marine and coastal ecosystems water quality. J Environ Manage Tourism 4 (1): 5-20

Hairiah K, Rahayu S. 2007. Measurements of carbon stored in various kinds of land use. World Agroforestry Center. ICRAF, SEA Regional Office, University of Brawijaya, Indonesia.

Hema M, Devi PI. 2015. Economic valuation of mangrove ecosystems of Kerala, India. J Environ Prof 4: 1-16

International Panel on Climate Change. 2003. IPPC guidelines for nation greenhouse inventories: Reference Manual IPCC. IPCC Expert Group Scoping Meeting Report, Geneva, Switzerland.

Kamaludin M, Aziz AA, Ibrahim NSC, Radam AA. 2018. A survey on willingness to pay for domestic water service attributes in Terengganu, Malaysia. J Sustain Sci Manag 4: 133-144.

Kolinug KH, Langi MA, Ratag SP, Nurmawan W. 2014. Zonation of the main plants making up mangroves based on the level of seawater salinity in the village of Teling, Tombariri District. In COCOS 5 (4)

Komiyama A, Ong JE, Poungparn S. 2008. Allometric, biomass, and productivity of mangrove forests: A review. Aquat Bot 89: 128-137.

Kusmana C, Sabiham S, Abe K, Watanabe H. 1992. An estimation of above-ground tree biomass of a mangrove forest in East Sumatra, Indonesia. Tropics 1: 243-257.

Kusmana C, Wilarso S, Hilwan I, Pamoengkas P, Wibowo C, Tiryana T, Triswanto A, Yunasfi, Hamzah. 2003. Mangrove rehabilitation techniques. Faculty of Forestry Bogor Agricultural University, Bogor.

Lahjie AM, Nouval B, Annisa AL, Ruslim Y, Kristiningrum R. 2019. Economic valuation from direct use of mangrove forest restoration in Balikpapan Bay, East Kalimantan, Indonesia. F1000Research 2019, 8: 9. DOI: 10.12688/f1000research.17012.1

Lal P. 2003. Economic valuation of mangroves and decision making in the Pacific. J Ocean Coast Manag 46 (9-10): 823-844.

Liquete C, Piroddi C, Drakou EG, Gurney L, Katsanevakis S. 2013. Current status and future prospects for the assessment of marine and coastal ecosystem services: a Systematic Review. J PLoS One 8 (7): e67737. DOI: 10.1371/journal.pone.0067737.

Malik, Abdul, Rasmus, Fensholt, Mertz, Ole. 2015. Economic valuation of mangroves for comparison with commercial aquaculture in south Sulawesi, Indonesia. Forests 6 (9): 3028-3044

Mehvar S, Filatova, Dastgheib A, van Stevenick EDR, Ranasinghe R. 2018. Quantifying economic value of coastal ecosystem services: A Review. J Mar Sci Eng 6 (5): 1-8. 
Mitchell, R. C. and R. T. Carson (1989). Using Surveys to Value Public Goods: The Contingent Valuation Method. Resources for the Future, Washington DC.

Mukherjee N, Sutherland WJ, Dicks L, Huge J, Koedam N, Guebas FD 2014. Ecosystem services valuations of mangrove ecosystem to inform decision making and future valuation exercises. PLoS One 9 (9): e107706. DOI: 10.1371/journal.pone.0107706.

Muliadi M, Lahjie AM, Simarangkir BDAS, Ruslim Y. 2017. Bioeconomic and environmental valuation of dipterocarp estate forest based on local wisdom in Kutai Kartanegara, Indonesia. Biodiversitas 18 (1): 401-408. [Indonesian]

Nauw. 2012.Composition and vegetation structure of mangrove forests in the village of Kumu, Tombariri, Minahasa Regency. Cocos 1 (1): 120.

Nybakken JW. 1992. Biologi Laut Suatu Pendekatan Ekologis. PT. Gramedia Pustaka Utama, Jakarta. [Indonesian]

Oktawati NO, Sulistianto E. 2015. Study of Mangrove Ecosystem Management in Kariangau Village, West Balikpapan District Through an Economic Approach. Borneo Harpodon J 113-121.

Pearce DW and Moran D. 1994. The economic value of biodiversity. Earth scan, London.

Putri DK, Subiyanto S, Awaluddin M. 2017. Analysis of the willingness to pay value and travel cost for making economic zone value maps for the coastal area of Marina and Puri Maerokoco Semarang using geographic information systems (GIS). J of Geodesy at Diponegoro University: 47-56

Rizal A, Dewanti LP. 2017. Using economic value to evaluate management options for fish biodiversity in the Sikakap Strait, Indonesia. Biodiversitas 18 (2): 575-581. [Indonesian]

Ruslim Y. 2011. Implementing reduced impact logging with mono-cable winch. J Trop For Manag 17 (3): 103-110. [Indonesian]

Ruslim Y, Sihombing R, Liah Y. 2016. Stand damage due to mono-cable winch and bulldozer yarding in a selectively logged tropical forest. Biodiversitas 17 (1): 222-228. [Indonesian]

Saraithong W. 2016. Estimating willingness to pay for safe beef. J Environ Manag Tourism 7 (13): 94-104.

Sina I, Maryunani, Batoro J, Harahab N. 2017. Analysis of total economic value of ecosystem mangrove forest in the coastal zone Pulokerto Village District of Kraton Pasuruan Regency. Int J Ecosys 7 (1): 1-10

Sathirathai S. 2003. "Economic valuation of mangroves and the roles of local communities in the conservation of natural resources: Case study of Suratthani, South of Thailand".
Setyawan AD, Winarno K, Purnama PC. 2003. Mangrove ecosystem in Java: 1. Recent status. Biodiversitas 4 (2): 133-145. [Indonesian]

Spalding MK. 2010. World Atlas of Mangrove. Earth Scan, London.

Spalding M, Kainuma M., Collins L. 2010. World atlas of mangroves (p. 319). A collaborative project of ITTO, ISME, FAO, UNEP-WCMC, UNESCO-MAB, UNU-INWEH and TNC, Earth scan, London.

Sulistiyowati, H. 2009. Mangrove biodiversity in Sempu Island Nature Reserve. J Sainstek 8 (1): 59-61. [Indonesian]

Sugiyono. 2015. Metode penelitian kombinasi (mix methods). Alfabeta, Bandung. [Indonesian]

Suprapto S, Kirana M, Susilowati I, Fauzi A. 2016. Economic valuation of mangrove restoration in Indonesia. J Dev Econ 16 (2): 121-130.

Supriharyono. 2000. Preservation and management regional natural resources tropical coast. Gramedia. Library, Jakarta. [Indonesian]

Salem ME, Mercer DE. 2012. The Economic value of mangroves: A Meta-Analysis. J Sustain 4: 359-383.

Turner RK, Pearce DW. 1990. The ethical foundations of sustainable economic development. Int Inst Environ Dev.

Turner TF, Collyer ML, Krabbenhoft ML. 2010. A general hypothesistesting framework for stable isotope ratios in ecological studies. Ecology 91: 2227-2233.

Van Gardingen MM. 2003. Financial and ecological analysis of management options for logged-over dipterocarp Forest in Indonesia Borneo. J For Ecol Manag: 1-29.

Wahyuni Y, Putri EI, Simanjuntak S. 2014. Total economic evaluation of mangrove Forests in the Mahakam Delta Region, Kutai Kartanegara Village, East Kalimantan. Wallacea For Res J: 1-12.

Warsidi, Endayani. 2017. Mangrove vegetation composition in Balikpapan Bay, East Kalimantan. Agrifor J: 115-124.

Widiastuti MM, Ruata NN, Arifin T. 2016. Ecosystem economic valuation mangroves in coastal areas Merauke Regency. Soc J Mar Econ Fish 11 (2): 147-159.

Wijaya S. 2018. Sustainable marine and fisheries development in supporting Indonesia as the world maritime axis. Maritime and Fisheries Research and Human Resources Agency, Jakarta. [Indonesian]

Winarni B, Lahjie AM, Simarangkir BDAS, Yusuf S, Ruslim Y. 2017. Tengkawang cultivation model in community forest using agroforestry system in West Kalimantan, Indonesia. Biodiversitas 18 (2):765-772. [Indonesian] 